\section{Effect of an Aqueous Nano- suspension of Clay Minerals on the Performance, Carcass Characteristics and Internal Organs of Broilers}

\author{
Nafez Al-Beitawi ${ }^{1 *}$, Khaled Elshuraydeh ${ }^{2}$, Mohammad Al- \\ Faqeih $^{2}$ and Moroug Zyadeh ${ }^{3}$
}

${ }^{1}$ Department of Animal Production, Jordan University of Science and Technology, Faculty of Agriculture, Irbid, Jordan

${ }^{2}$ National Center for Research and Development, The Higher Council for Science and Technology, Amman, Jordan

${ }^{3}$ Department of Biology, Jerash University, Faculty of science, Jerash, Jordan

\begin{abstract}
This study examined the effect of different levels $(1 \%, 1.5 \%$ and $2 \%$ ) of an aqueous nanosuspension of clay minerals offered at different intervals (once per week and once every two weeks) compared to tap water with or without antibiotics supplementation on the growth performance, carcass characteristics and internal organs measurements of broilers. In all 640 one-day-old unsexed Lohman broiler chicks were randomly allocated into 32 pens $(1.15 \mathrm{~m} \times 2.10$ $\mathrm{m}$ ) in an open-sided house ( 8 treatments $\times 4$ replicates $\times 20$ chicks). A statistical analysis of the results shows that the $2 \%$ aqueous nanosuspension of clay minerals offered once every two weeks significantly improved the growth performance, carcass characteristics and internal organs measurements of the broilers. We can conclude that nanotechnology is a promising new tool for improving broiler production; however, additional studies are needed in this field.

Keywords: Aqueous nanosuspension; Broilers; Carcass characteristics; Internal organs
\end{abstract}

\section{Introduction}

The poultry industry is the fastest growing source of meat, as a result of genetic selection, health management practices and

*Corresponding author: Nafez Al-Beitawi, Department of Animal Production, Faculty of Agriculture, Jordan University of Science and Technology, Irbid, Jordan, P.O.Box3005, Al-Jubeiha- 11141, Amman, Jordan, Tel: +962 796440448; E-mail: beitawi@just.edu.jo

Citation: Al-Beitawi N, Elshuraydeh K, Al-Faqeih M, Zyadeh M (2017) Effect of an Aqueous Nanosuspension of Clay Minerals on the Performance, Carcass Characteristics and Internal Organs of Broilers. J Nanotechnol Nanomed Nanobiotechnol 4: 013.

Received: August 17, 2016; Accepted: March 14, 2017; Published: March 31, 2017 improved nutrition. Consumers are moving from the consumption of whole chickens toward the consumption of cuts and further processed broiler products [1]. The increase in further processing has increased concerns about the quality and control of factors influencing broiler performance, carcass cuts and meat quality.

The growth and development of muscles consists of hyperplasia, where the total number of myofibers increases and hypertrophy, which leads to the increased volume of the individual my fibers $[2,3]$.

The experimental biology symposium entitled "Nanotechnology Research: Applications in Nutritional Sciences" was organized to highlight the emerging applications of nanotechnology in food and nutrition sciences and to suggest ways of further integrating of these emerging technologies with nutrition research. Nanotechnology has the potential to revolutionize agriculture, veterinary medicine, animal health and other areas of animal production [4]. Moreover reported that nanotechnology can increase the cost-effectiveness of poultry and meat products with natural properties [5]. In the area of nutrition it is possible to apply nanotechnology in several ways such as obtaining information about a nutrient, avoiding nutrient degradation and obtaining greater availability [6]. Minerals are one of the most widelyused supplements in animal nutrition [7]. Developed highly available nanoparticles of ferric phosphate, demonstrating that the nanoscale of this nutrient increased its nutritional value. However, in research on the mineral nutrition of poultry, several minerals are important. Therefore, this study focuses on the effect of nanotechnology on clay minerals obtained from different areas of Jordan as an inexpensive source of several minerals, and examines their effect on broiler growth performance, carcass characteristics and internal organs measurements compared with or without antibiotics.

\section{Materials and Methods}

Experimental birds and rearing conditions: A total of 640 one-dayold unsexed Lohman broiler chicks were purchased from a commercial hatchery. The average body weight of the chicks was $40 \mathrm{~g}$. The chicks were randomly allocated into 32 pens $(1.15 \mathrm{~m} \times 2.10 \mathrm{~m})$ in an open-sided house ( 8 treatments $\times 4$ replicates $\times 20$ chicks). Chicks were vaccinated against the Newcastle (ND) HB1 strain and the Infectious Bronchitis (IB) IB120 strains at 7 days of age, the La Sota strain at 21-days of age and against Infectious Bursal Disease (IBD) at 13-days of age. Feed and water were offered ad-libitum. The treatments used are listed in table 1 . The experimental diets were given once each week or once every two weeks and the other days the chicks were fed the basal rations without any supplementations.

Experimental rations: Chicks were fed a starter ration from one to 21-days of age and a finisher ration from 22 to 36-days of age (Table 2).

All rations were formulated to meet the requirements recommended by the strain guide. A randomized sample from each starter and finisher diets were collected for proximate analysis by the procedure described by the Association of Official Analytical Chemists [8].

Preparation of clay minerals sample: A sample of clay minerals was used for the preparation of the aqueous nanosuspension used in the 
Citation: Al-Beitawi N, Elshuraydeh K, Al-Faqeih M, Zyadeh M (2017) Effect of an Aqueous Nanosuspension of Clay Minerals on the Performance, Carcass Characteristics and Internal Organs of Broilers. J Nanotechnol Nanomed Nanobiotechnol 4: 013.

- Page 2 of 5 •

\begin{tabular}{|c|c|c|c|c|c|c|}
\hline \multirow{2}{*}{ Groups } & \multicolumn{5}{|c|}{ Receive Diets } \\
\cline { 2 - 7 } & Basal diet & Antibiotics & Vaccines & $\mathbf{1 \%}$ aqueous nanosuspension & $1.5 \%$ aqueous nanosuspension & 2\% aqueous nanosuspension \\
\hline 1- Control & + & + & + & + & & \\
\hline 2- Control & + & & & & \\
\hline 3- Control & + & & & + & + \\
\hline $4(\mathrm{~T} 1)$ & + & & & & + \\
\hline $5(\mathrm{~T} 2)$ & + & & & & + \\
\hline $6(\mathrm{~T} 3)$ & + & & & & + \\
\hline $7(\mathrm{~T} 4)$ & + & & & & + \\
\hline $8(\mathrm{~T} 5)$ & + & & & & + \\
\hline $9(\mathrm{~T} 6)$ & + & & & & + \\
\hline
\end{tabular}

Table 1: Scheme of treatments.

T1- offered one time per week, T2- offered one time per two weeks, T3- offered one time per week, T4- offered one time per two weeks, T5- offered one time per week, T6- offered one time per two weeks

\begin{tabular}{|c|c|c|}
\hline Ingredient (g/k) & Starter & Finisher \\
\hline Corn & 615 & 695 \\
\hline Soybean meal & 340 & 237 \\
\hline Broiler concentrate & 20 & 40 \\
\hline $\mathrm{CaCO}_{3}$ & 12.5 & 12.3 \\
\hline Dicalcium phosphate & 7.2 & 10 \\
\hline $\mathrm{NaCl}$ & 2.5 & 2.5 \\
\hline Lysine & 0.3 & - \\
\hline Methionine & - & 0.7 \\
\hline *Vitamin-Mineral premix & 2.5 & 2.5 \\
\hline Total & $1000 \mathrm{~g}$ & $1000 \mathrm{~g}$ \\
\hline \multicolumn{3}{|l|}{ Calculated feeding value } \\
\hline Crude protein (\%) & 22.30 & 18.73 \\
\hline Metabolizable energy (MJ) & 12.30 & 12.65 \\
\hline Lysine (\%) & 1.26 & 1.05 \\
\hline Methionine + Cystine (\%) & 0.97 & 0.65 \\
\hline \multicolumn{3}{|l|}{ Analyzed feeding value } \\
\hline DM (\%) & 91.50 & 91.20 \\
\hline Crude Protein (\%) & 22.20 & 18.80 \\
\hline
\end{tabular}

Table 2: Composition of experimental rations.

*Vitamin: mineral Premix: Provided the following: 2,000,000 IU vitamin A; 400,000 IU Vitamin D3; 400 mg Vitamin E; 200mg Vitamin B1; 800 mg Vitamin B2; 4,000 mg Nicotinic acid; 2,000 mg Pantothenic acid; $300 \mathrm{mg}$ Vitamin K; $200 \mathrm{mg}$ Folic acid; $300 \mathrm{mg}$ Vitamin B6; $50 \mathrm{mg} \mathrm{Co} ; 1,600 \mathrm{Cu} ; 6,421 \mathrm{mg} \mathrm{Fe}$; 156 mg I; 12,800 mg Mn; 32 mg Se; 9,000 mg Zn; 100 mg Choline Chloride.

experiment. The sample of clay minerals obtained from Jordan was mechanically wet ground to the nano-scale using two adjacent concentric cylinders (inner diameter of the outer cylinder-outer diameter of inner cylinder $=1 \mathrm{~mm})$ with a rotating inner cylinder $(12,000 \mathrm{rpm})$ and a fixed outer cylinder at room temperature for 1 minute. The pot time of the aqueous nanosuspension was approximately about onehalf hour and the suspensions were further stabilized by mechanical stirring. Samples of the aqueous nanosuspensions were imaged under a transmission electron microscope, and the image revealed the "unite structure" of the clay minerals, i.e., "nano-flake" with length of ca.100 $\mathrm{nm}$ and thickness of ca. $1 \mathrm{~nm}$ (Figure 1). The chemical composition of the bulk clay mineral materials was analyzed for its major elements. The results from a standard inductively coupled plasma-atomic

emission spectrometry analysis revealed the chemical composition as shown in table 3.

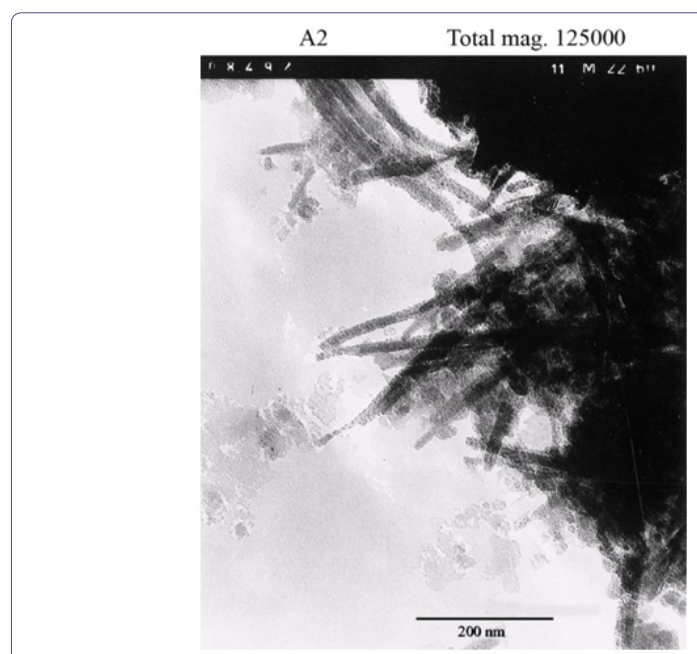

Figure 1: Image reveals the "unite structure" of the clay minerals (nano-flake")

\begin{tabular}{|c|c|}
\hline Element & $\%$ \\
\hline $\mathrm{Na}_{2} \mathrm{O}$ & 0.13 \\
\hline $\mathrm{MgO}$ & 3.47 \\
\hline $\mathrm{Al}_{2} \mathrm{O}_{3}$ & 20.08 \\
\hline $\mathrm{SiO}_{2}$ & 55.67 \\
\hline $\mathrm{K}_{2} \mathrm{O}$ & 2.45 \\
\hline $\mathrm{CaO}$ & 2.15 \\
\hline $\mathrm{TiO}_{2}$ & 2.54 \\
\hline $\mathrm{Fe}_{2} \mathrm{O}_{3}$ & 13.47 \\
\hline
\end{tabular}

Table 3: Chemical composition of clay minerals sample.

Preparation of aqueous nanosuspensions of clay minerals: The aqueous nanosuspensions of clay minerals were prepared with 3 different concentrations $(1 \%, 1.5 \%$ and $2 \%$ ) by adding 10,15 and $20 \mathrm{~g}$ of the clay minerals sample respectively to one liter of potable. The $\mathrm{pH}$ value of the aqueous nanosuspensions was 8.3-9.1 (alkaline). The above procedure was designed and implemented by Prof. Khaled Elshuraydeh, Secretary General of the Higher Council for Science and Technology and vice president of the National Center for Research and Development, Amman, Jordan. 


\section{Measurements}

Live body weight and feed intake: Live Body Weight (LBW) and Feed Intake (FI) were measured each week. Body Weight Gain (BWG) was calculated on a weekly basis throughout the experimental period (36days of age). The amount of feed consumed was recorded each week and Cumulative Feed Intake (CFI) was calculated at the end of the experiment (36-days of age). Additionally the Feed Conversion Ratio (FCR) was calculated at 36-days of age.

Carcass characteristics: At the end of the experiment (36-days of age). 5 broiler chickens from each replicate within each treatment were randomly selected and weighed to obtain their LBW. These animals were sacrificed using sharp knife and completely bled and the feathers were plucked. The head viscera and shanks were removed. The carcass was held for one hour to remove excess water. Maintained overnight in a refrigerator at $4 \pm 1^{\circ} \mathrm{C}$ and then weighed. The dressing percentage was calculated without the giblets.

The thighs, drumsticks, breasts and wings were separated and weighed individually. Data from these measurements were used to calculate the percentage of each part to the total live weight.

Internal organs: The heart, liver, gizzard, proventriculus, pancreas, spleen and bursa of fabricious gland were individually weighed.

Statistical analysis: Each pen was used as an experimental unit. All statistical analysis were perform using SPSS version 17 [9]. Collected data were statistically analyzed by two ways ANOVA to examine the effects of feeding treatments with or without antibiotics and their interactions. When interaction effect were significant $(\mathrm{P}<0.05)$ differences between means were analyzed by least square means comparison. Differences considered significant at $(\mathrm{P}<0.05)$.

\section{Results}

\section{Growth performance}

Performance data (means \pm SE) at day 36 of age are presented in table 4 . The obtained results show that, the use of $2 \%$ concentration of the Aqueous Nanosuspension of clay minerals (ANS) once every two weeks significantly improved the growth performance of broiler chickens in terms of the LBW, BWG and FCR. Moreover the results show that the ANS of clay minerals had a similar effect as the antibiotics.

\section{Carcass characteristics}

Results for carcass characteristics parameters (dressing and cuts percentages) at day 36 of age are presented in table 5. The values of the dressing, breasts, thighs and drumsticks significantly increased in birds receiving the ANS of clay minerals (2\%) offered once every two weeks. The dressing and cuts percentages were 73.45, 28.25, 12.88 and 10.71 for the dressing, breast, thigh and drumstick, respectively.

\section{Internal organs parameters}

Table 6 shows the means \pm SE of the internal organ parameters at day 36 of age. Notably the use of the $2 \%$ ANS of clay minerals offered once every two weeks increased the weights of the heart, liver, gizzard, proventriculus, pancreas, spleen and the bursa of fabric us gland compared with the other treatments.

\section{Discussion}

\section{Growth performance}

We suggest that the favourable results obtained herein could be attributed to the concentration and dose of the nanoflakes of clay minerals. The general approach is to develop nano-size materials or carriers to improve the function of food additives. Minerals are one of the most widely used supplements in poultry nutrition. However, the way forms of the minerals and how they are employed influences their bioavailability. If the minerals have a low bioavailability the animal cannot utilize them and they will be eliminated [10]. It has been reported that the properties of nanoparticles make them attractive for improving the absorption and bioavailability of mixed substances, such as minerals and vitamins [11]. This could explain the improvement in the growth performance of the broiler chickens fed the ANS of clay minerals. Additionally the reason why nanoparticles are so different from larger particles is attributed to two effects: First the effect of quantum points which is a type of nanostructure that behave similarly to a single atom. The second effect is related to those atoms of nonmaterial's are more stable than those of larger structures. Moreover it has been reported that nanoparticles have a surface area much larger than microparticles [12]. As the size of the nanoparticles decreases, the surface area for chemical reactions increases. Therefore, reactivity increases 1000 times, which may improve the digestion and absorption of the minerals and this is reflected in the improvement in the growth performance of the broiler chickens. Nanotechnology tools could also be applied in broiler nutrition to identify bioactive components their liberation in specific sites of action and for avoiding degradation [6]. To create these tools, much additional research in this field is required.

\section{Carcass characteristics}

We suggest that the favourable effects of ANS can be attributed to the concentration and dose of the nanoflakes of clay minerals [10]. reported that nanotechnology has the potential to change the particles of materials from a large scale to nano-scale particles ( 1 to 300 nanometers in size). At this small size the properties and characteristics can differ considerably with particles of larger sizes [13]. Unfortunately there is a lack or even null information regarding the use of nanotechnology in broiler feeding and nutrition. Minerals are one of the most widely used supplements in poultry nutrition. However minerals are available in a variety of forms, and periodically problems arise due to the lack of knowledge of the composition and/or the stability of the mineral salts. It should also be emphasized that various processes used in manufacturing likely influence minerals bioavailability. If the minerals have a low bioavailability, the bird cannot utilize them, and they will often be eliminated. Additionally the reason why nonmaterial are different from larger particles is due to 2 factors or effects [14]. First quantum points are a type of nanostructure that is a few nanometers in size and they behave in similar manner as a single atom. Second, the atoms of nanomaterials are more stable than those with larger structures because the energy required to join adjacent atoms is less due to surface area. Moreover, stated that nanoparticles have a surface area much larger than microparticles, and as the size of the nanoparticles decreases, the surface area for chemical reactions increases, (reactivity increases 1000 times) which may improve the digestion and absorption of the minerals, and result in the improved growth performance and carcass characteristics of broiler chickens [12]. Furthermore, in more recent studies and indicated that nanotechnology affected the expression of genes directly or indirectly responsible for muscle development and Fibroblast Growth Factor 2 (FGF2), which may also explain the improvement in carcass characteristics when an ANS of clay minerals are used $[15,16]$. In another recent study, reported that the potential applications of nanotechnology in potential and mechanism 


\begin{tabular}{|c|c|c|c|c|c|c|c|c|}
\hline $\begin{array}{l}\text { Treatments } \\
\text { Parameters }\end{array}$ & C I With antibiotics & $\begin{array}{l}\text { C II Without } \\
\text { antibiotics }\end{array}$ & $1 \% / 1 w k$ ANS & $1 \% / 2$ wks ANS & $1.5 \% / 1 w k$ ANS & $1.5 \% / 2 \mathrm{wks}$ ANS & $2 \% / 1 w k$ ANS & $2 \% / 2$ wks ANS \\
\hline $\begin{array}{l}\text { Live Body Weight } \\
\text { (LBW) Kg }\end{array}$ & $2.08 \pm 0.02^{\mathrm{ab}}$ & $2.02 \pm 0.03^{b c}$ & $1.95 \pm 0.03^{\mathrm{d}}$ & $2.03 \pm 0.03^{\mathrm{bc}}$ & $1.99 \pm 0.02^{\mathrm{cd}}$ & $2.04 \pm 0.03^{b}$ & $2.04 \pm 0.02^{b}$ & $2.10 \pm 0.02^{\mathrm{a}}$ \\
\hline $\begin{array}{l}\text { Body Weight Gain } \\
\text { (BWG) Kg }\end{array}$ & $2.04 \pm 0.02^{\mathrm{a}}$ & $1.98 \pm 0.03^{\mathrm{bc}}$ & $1.91 \pm 0.03^{c}$ & $1.99 \pm 0.03^{b}$ & $1.95 \pm 0.02^{\mathrm{bc}}$ & $2.00 \pm 0.03^{\mathrm{ab}}$ & $2.00 \pm 0.02^{\mathrm{ab}}$ & $2.06 \pm 0.02^{\mathrm{a}}$ \\
\hline $\begin{array}{l}\text { Cumulative Feed } \\
\text { Intake (CFI) Kg }\end{array}$ & $3.43 \pm 0.04^{a}$ & $3.40 \pm 0.04^{\mathrm{a}}$ & $3.23 \pm 0.03^{c}$ & $3.30 \pm 0.04^{b}$ & $3.31 \pm 0.03^{b}$ & $3.41 \pm 0.03^{\mathrm{a}}$ & $3.37 \pm 0.04^{\mathrm{ab}}$ & $3.30 \pm 0.03^{b}$ \\
\hline $\begin{array}{l}\text { Feed Conversion } \\
\text { Ratio (FCR) }\end{array}$ & $1.65 \pm 0.02^{\mathrm{bc}}$ & $1.68 \pm 0.01^{\mathrm{a}}$ & $1.66 \pm 0.01^{\mathrm{bc}}$ & $1.63 \pm 0.01^{\mathrm{c}}$ & $1.66 \pm 0.01^{\mathrm{ab}}$ & $1.67 \pm 0.01^{\mathrm{ab}}$ & $1.65 \pm 0.01^{\mathrm{bc}}$ & $1.57 \pm 0.01^{\mathrm{d}}$ \\
\hline
\end{tabular}

Table 4: Effect of aqueous nanosuspension of clay minerals on growth performance of broiler chickens at 36-days of age.

a-b means with different superscript in the same row are significantly different at $\mathrm{P}<0.05$.

\begin{tabular}{|c|c|c|c|c|c|c|c|c|}
\hline $\begin{array}{l}\text { Treatments } \\
\text { parameters }\end{array}$ & C I With antibiotics & C II Without antibiotics & $1 \% / 1$ wk ANS & $1 \% / 2$ wks ANS & $1.5 \% / 1 w k$ ANS & $1.5 \% / 2 w k s$ ANS & $2 \% / 1$ wk ANS & $2 \% / 2 w k s$ ANS \\
\hline Dressing $\%$ & $72.27 \pm 0.34^{b}$ & $68.15 \pm 0.27^{d}$ & $69.76 \pm 0.30^{\circ}$ & $72.17 \pm 0.28^{b}$ & $69.85 \pm 0.30^{c}$ & $70.11 \pm 0.30^{c}$ & $70.45 \pm 0.35^{c}$ & $73.45 \pm 0.30^{\mathrm{a}}$ \\
\hline Breast \% & $27.45 \pm 0.32^{\mathrm{b}}$ & $25.18 \pm 0.25^{d}$ & $26.40 \pm 0.35^{\circ}$ & $27.42 \pm 0.27^{\mathrm{b}}$ & $26.52 \pm 0.26^{c}$ & $26.71 \pm 0.30^{\circ}$ & $26.80 \pm 0.20^{\circ}$ & $28.25 \pm 0.23^{a}$ \\
\hline Thigh \% & $12.88 \pm 0.20 a^{b}$ & $10.43 \pm 0.20^{d}$ & $11.35 \pm 0.27^{c}$ & $12.60 \pm 0.25^{b}$ & $11.75 \pm 0.30^{\circ}$ & $12.05 \pm 0.26^{c}$ & $11.60 \pm 0.24^{c}$ & $13.17 \pm 0.30^{\mathrm{a}}$ \\
\hline Drumstick \% & $8.72 \pm 0.32^{\circ}$ & $7.49 \pm 0.24^{e}$ & $7.95 \pm 0.20^{d}$ & $9.17 \pm 0.21^{b}$ & $7.86 \pm 0.22^{\text {de }}$ & $9.60 \pm 0.30^{b}$ & $8.15 \pm 0.19^{d}$ & $10.71 \pm 0.25^{\mathrm{a}}$ \\
\hline Wings \% & $8.72 \pm 0.24^{a}$ & $5.17 \pm 0.15^{\mathrm{d}}$ & $6.56 \pm 0.22^{\circ}$ & $8.15 \pm 0.25^{b}$ & $6.47 \pm 0.20^{c}$ & $6.62 \pm 0.28^{c}$ & $7.15 \pm 0.20^{c}$ & $8.95 \pm 0.20^{c}$ \\
\hline
\end{tabular}

Table 5: Effect of nanosuspension of clay minerals on carcass characteristics of broiler chickens at 36 -days of age.

a-e means with different superscript in the same row are significantly different $p<0.05$.

\begin{tabular}{|c|c|c|c|c|c|c|c|c|}
\hline $\begin{array}{c}\text { Treatments } \\
\text { arameters }\end{array}$ & C I With antibiotics & $\begin{array}{l}\text { C II Without } \\
\text { antibiotics }\end{array}$ & $1 \% / 1$ wk ANS & $1 \% / 2$ wks ANS & $1.5 \% / 1 w k$ ANS & $1.5 \% / 2 \mathrm{wks}$ ANS & $2 \% / 1$ wk ANS & $2 \% / 2$ wks ANS \\
\hline Heart $(\mathrm{g})$ & $13.35 \pm 0.60^{\mathrm{b}}$ & $11.38 \pm 0.53^{c}$ & $12.79 \pm 0.42^{\mathrm{b}}$ & $13.72 \pm 0.29^{b}$ & $11.95 \pm 0.27^{c}$ & $13.45 \pm 0.59^{b}$ & $12.87 \pm 0.37^{b}$ & $14.98 \pm 0.67^{a}$ \\
\hline Liver (g) & $61.03 \pm 0.25$ & $53.52 \pm 0.27^{e}$ & $58.54 \pm 0.25^{d}$ & $64.15 \pm 0.28^{\mathrm{b}}$ & $63.15 \pm 0.32^{\mathrm{c}}$ & $64.50 \pm 0.31^{\mathrm{b}}$ & $63.00 \pm 0.29^{\circ}$ & $66.90 \pm 0.75^{\mathrm{a}}$ \\
\hline Gizzard (g) & $29.47 \pm 0.20^{d}$ & $25.15 \pm 0.19^{f}$ & $27.45 \pm 0.40^{\mathrm{e}}$ & $29.32 \pm 0.17^{\mathrm{d}}$ & $26.16 \pm 0.15^{f}$ & $31.48 \pm 0.26^{c}$ & $33.69 \pm 0.27^{b}$ & $36.15 \pm 0.26^{a}$ \\
\hline Proventriculus (g) & $8.68 \pm 0.07^{b}$ & $7.00 \pm 0.05^{\mathrm{e}}$ & $7.72 \pm 0.03^{d}$ & $9.00 \pm 0.10^{\mathrm{b}}$ & $8.37 \pm 0.09^{c}$ & $8.75 \pm 0.10^{b}$ & $8.87 \pm 0.07^{b}$ & $9.65 \pm 0.10^{a}$ \\
\hline Spleen (g) & $3.79 \pm 0.03^{d}$ & $2.55 \pm 0.01^{f}$ & $2.65 \pm 0.03^{e}$ & $4.62 \pm 0.04^{b}$ & $3.90 \pm 0.04^{d}$ & $4.35 \pm 0.02^{c}$ & $3.80 \pm 0.02^{\mathrm{d}}$ & $4.96 \pm 0.07^{\mathrm{a}}$ \\
\hline Bursa (g) & $7.07 \pm 0.03^{c}$ & $3.56 \pm 0.09^{g}$ & $4.35 \pm 0.01^{f}$ & $8.46 \pm 0.05^{b}$ & $5.47 \pm 0.03^{e}$ & $6.00 \pm 0.02^{\mathrm{d}}$ & $6.15 \pm 0.02^{\mathrm{d}}$ & $8.97 \pm 0.07^{a}$ \\
\hline
\end{tabular}

Table 6: Effect of aqueous nanosuspension of clay minerals on internal organs of broiler chickens at 36-days of age.

a-g means with different superscript in the same row are significantly different $p<0.05$.

of nanotechnology in the broiler industry requires more research to gather sufficient knowledge in this field [4].

\section{Internal organs parameters}

To our knowledge there is no literature on effect of an aqueous nanosuspension of clay minerals on the internal organs of broiler chickens. Therefore, we will discuss the available literatures in the field of nanotechnology in agriculture specifically in broiler production. We suggest that the favourable effects of the ANS of clay minerals obtained in this study are attributable to the concentration and dose of nanoflakes of clay minerals. For the purpose of the present study, we use the definition endorsed by the National Nanotechnology Institute (NNI), which defines nanotechnology as research and technology development at the atomic, molecular, or macromolecular scale, used to control the creation and use of structures, and systems with a length of 1-100 nanometers (nm). Such constructs must also have novel properties and functions because of their small size. At this scale, the physical, chemical and biological properties of materials differ fundamentally (and even unexpectedly) from those at larger scales [17]. The general approach is to develop nano-size materials or carriers to improve the function of feed additives. Minerals are one of the most widely used supplements in poultry nutrition. However, the way in which minerals are obtained influences their bioavailability, if they have a low bioavailability, the animal cannot utilize them, and they will be eliminated. Minerals bioavailability can be influenced by many factors. We believe that one another factor causing the positive effect of the ANS in the present study is the improvement of the availability of minerals as a result of treating this clay with nanotechnology tool. Reported that nanoparticles have a surface area much larger than microparticles, which may lead to improved digestion and absorption of minerals, which is then reflected in the improvement of the internal organ weights of the broiler chickens [12]. Sodium $(\mathrm{Na}+)$ one of the minerals found in the chemical composition of the ANS of clay minerals is the principle cation of extracellular fluid and is involved in several functions such as the regulation of extracellular fluid volume, acid-base balance, cell membrane potential, and the absorption of glucose and amino acids [18]. This could be another factor explaining the results of this study.

\section{Conclusion}

The results of the present study suggest that feeding a $2 \%$ aqueous nanosuspension of clay minerals to broiler chicks once every two 
weeks could improve growth performance, carcass characteristics and internal organs measurements, which are promising results. Further researches are needed to determine the mechanism of how these nanoparticles affect absorption and utilization of the minerals. Moreover, toxicity studies are strongly recommended to investigate of using clay minerals in the form of aqueous nanosuspension.

\section{References}

1. Smith DP, Aceton JC (2001) Marination, cooking, and curing of poultry products. In: Sans AR (eds.). Poultry Meat Processing, CRC Press LLC, USA.

2. Smith JH (1963) Relation of Body Size to Muscle Cell Size and Number in the Chicken. Poultry Science. 42: 283-290.

3. Sobolewska A, Elminowska-Wenda G, Bogucka J, Szpinda M, Walasik K, et al. (2011) Myogenesis--possibilities of its stimulation in chickens. Folia Biol (Krakow) 59: 85-90.

4. Sekhon BS (2012) Nanoprobes and their applications in veterinary medicine and animal health. Research Journal of Nanoscience Nanotechnology 2: $1-16$.

5. Singh M, Manikandan S, Kumaraguru AK (2011) Nanoparticles: A New Technology with Wide Applications. Research Journal of Nanoscience and Nanotechnology. 1: 1-11

6. Ross SA, Srinivas PR, Clifford AJ, Lee SC, Philbert MA, et al. (2004) New technologies for nutrition research. J Nutr 134: 681-685.

7. Rohner F, Ernst FO, Arnold M, Hilbe M, Biebinger R, et al. (2007) Synthesis characterization, and bioavailability in rats of ferric phosphate nanoparticles. J Nutr 137: 614-619.

8. Andrews $\mathrm{WH}$ (1994) Update on validation of microbiological methods by AOAC International. J AOAC Int 77: 925-931.
9. Norušis MJ (2008) SPSS Statistics 17.0 Guide to Data Analysis. SPSS Inc, Prentice Hall, New Jersey, USA.

10. Ramirez-Mella M, Hernandez-Mendo O (2010) Nanotechnolgy on animal production. Tropical and Subtropical Agroecosystems 12: 423-429.

11. World Health Organization (WHO) (2008) IFOSAN Information Note. 01/2008- Nanotechnology, WHO, Geneva, Switzerland.

12. Buzea C, Pacheco II, Robbie K (2007) Nanomaterials and nanoparticles: Sources and toxicity. Biointerphases 2: 17-71.

13. Romero- Perez A, Garcia-Garcia E, Zavaleta-Mancera A, Ramirez- Bribiesca JE, Revilla-Vazquez A, et al. (2010) Designing and evaluation of sodium selenite nanoparticles in vitro to improve selenium absorption in ruminants. Vet Res Commun 34: 71-79.

14. Roduner $E$ (2006) Size matters: why nanomaterials are different. Chem Soc Rev 35: 583-592.

15. Hotowy AM, Sawos E, Pineda L, Sawosz F, Grodzik M et al. (2012) Silver nanoparticles administered to chicken affect VEGFA and FGF2 gene expression in breast muscle and heart. Nanoscale Res Lett 7: 418.

16. Sawosz F, Pineda L, Hotowy AM, Hyttel P, Sawosz E, et al. (2012) Nano-nutrition of chicken embryos. The effect of silver nanoparticles and glutamine on molecular responses, and the morphology of pectoral muscle: the effect of silver nanoparticles and glutamine on molecular responses, and the morphology of pectoral muscle. Baltic Journal of Comparative \& Clinical Systems Biology 2: 29-45.

17. Scott NR (2005) Nanotechnology and animal health. Revue Scientifique et Technique (International Office of Epizootics 24: 425-432.

18. Mongin $P$ (1980) Electrolyte in nutrition. A review of basic principles and practical applications in poultry and science. Proceeding of 3rd Annual International Minerals Conference, Orlando FL, USA. 